(2)

\title{
Impact of proton pump inhibitor treatment on pancreatic beta-cell area and beta-cell proliferation in humans
}

\section{Thomas G K Breuer', Laura Borker', Daniel R Quast', Andrea Tannapfel' Wolfgang E Schmidt ${ }^{1}$, Waldemar Uhl ${ }^{3}$ and Juris J Meier ${ }^{1}$}

'Diabetes Division, St. Josef-Hospital, Ruhr-University Bochum, Bochum, Germany, ${ }^{2}$ Institute for Pathology, Ruhr-University Bochum, Bochum, Germany, and ${ }^{3}$ Department of Surgery, St. Josef-Hospital,

Ruhr-University Bochum, Bochum, Germany
Correspondence should be addressed to J J Meier

Email

juris.meier@rub.de

\begin{abstract}
Introduction: Gastrin has been shown to promote beta-cell proliferation in rodents, but its effects in adult humans are largely unclear. Proton pump inhibitors (PPIs) lead to endogenous hypergastrinaemia, and improved glucose control during PPI therapy has been reported in patients with diabetes. Therefore, we addressed whether PPI treatment is associated with improved glucose homoeostasis, islet cell hyperplasia or increased new beta-cell formation in humans. Patients and methods: Pancreatic tissue specimens from 60 patients with and 33 patients without previous PPI therapy were examined. The group was subdivided into patients without diabetes $(n=27)$, pre-diabetic patients $(n=31)$ and patients with diabetes $(n=35)$.

Results: Fasting glucose and $\mathrm{HbA}_{1 \mathrm{c}}$ levels were not different between patients with and without PPI therapy ( $P=0.34$ and $P=0.30$ respectively). Beta-cell area was higher in patients without diabetes than in patients with pre-diabetes or diabetes $(1.33 \pm 0.12 \%, 1.05 \pm 0.09 \%$ and $0.66 \pm 0.07 \%$ respectively; $P<0.0001)$. There was no difference in beta-cell area between patients with and without PPI treatment $(1.05 \pm 0.08 \%$ vs $0.87 \pm 0.08 \%$, respectively; $P=0.16)$. Beta-cell replication was rare and not different between patients with and without PPI therapy $(P=0.20)$. PPI treatment was not associated with increased duct-cell replication $(P=0.18)$, insulin expression in ducts $(P=0.28)$ or beta-cell size $(P=0.63)$.

Conclusions: These results suggest that in adult humans, chronic PPI treatment does not enhance beta-cell mass or beta-cell function to a relevant extent.

\section{Introduction}

A beta-cell deficit has been demonstrated in patients with both type 1 and type 2 diabetes (1, 2, 3). In addition, in patients with diabetes secondary to exocrine pancreatic diseases, the number of pancreatic beta cells is reduced (4). Strategies aiming to replenish beta-cell mass have therefore been proposed as potential future therapies for patients with diabetes (5). Although embryonic stem cell-derived beta cells appear to be an intriguing source of new beta cells, such approaches are still far away from clinical application. In addition, therapeutic attempts to generate insulin-secreting cells from adult stem cells

www.eje-online.org DOI: 10.1530/EJE-16-0320 (c) 2016 European Society of Endocrinology Printed in Great Britain residing in the bone marrow, spleen or liver have not yet been sufficiently successful to allow for their application in humans (6). Therefore, enhancing the formation of new beta cells in the adult human pancreas might be a more realistic treatment strategy. Although the exact sources of new beta cells in adult humans are still debated, most investigators now agree that beta cells can be derived from the replication of existing beta cells and the potential transdifferentiation of duct cells into beta cells (7). Although the former pathway can be readily detected in human pancreatic specimens using specific 
proliferation markers, new beta-cell formation from duct cells can only indirectly be inferred from the expression of insulin in exocrine ducts.

A number of studies have provided evidence that beta-cell replication still happens in the postnatal human pancreas $(8,9,10)$. However, the frequency of beta-cell replication sharply declines during childhood $(8,11)$, and the capacity of beta-cell proliferation in adult humans seems to be rather low (12). This decline in beta-cell replication with ageing has been associated with changing expression patterns of certain cell cycle regulators, such as p16 (13). Nevertheless, increased formation of beta cells can still be observed during certain conditions, such as pregnancy or the manifestation of type 1 diabetes (14, $15)$, suggesting that there is still a potential to enhance new beta-cell formation, even later in life.

A number of compounds or endogenous factors have been suggested to enhance beta-cell proliferation. Amongst those, the incretin hormone - glucagon-like peptide 1 (GLP-1) - and the incretin-based therapies have been shown to increase beta-cell mass in various rodent models $(16,17,18)$. However, on more careful analysis, these effects were primarily detectable in very young rats and mice, but rather absent in older animals $(19,20)$. Other factors that have been proposed to drive beta cells into proliferation include the gestational hormone prolactin, serotonin, betacellulin and IGF-1 $(21,22,23,24)$.

A potential role in the regulation of beta-cell proliferation has also been suggested for the gut hormone gastrin, which is released from gastric ECL cells and primarily acts to stimulate gastric acid secretion (25). Thus, an increase in beta-cell mass has been observed in various rodent models treated with a combination of gastrin and epidermal growth factor $(26,27)$. In addition, combining GLP-1 and gastrin has been successful in stimulating new beta-cell formation in rodents (28). More recently, gastrin treatment has also been shown to enhance beta-cell regeneration after a 95\% partial pancreatectomy in rats (29).

Consistent with these experimental data in rodents, we have observed previously marked islet hyperplasia and high rates of beta-cell proliferation adjacent to gastrinproducing tumours (gastrinomas) in the adult human pancreas (10). However, these effects were only present in the direct proximity of the tumours, where the local concentrations of gastrin are likely to be very high. One way to raise the endogenous secretion of gastrin is through the administration of proton pump inhibitor (PPI) drugs. Thus, a compensatory rise in gastrin levels by 2- to 10-fold is typically found during PPI treatment (30). It is yet unknown, whether these modest elevations in circulating gastrin levels have an impact on beta-cell mass and beta-cell proliferation in adult humans.

Therefore, in this study, we examined human pancreatic tissue samples that were collected at surgery to address whether endogenous hypergastrinaemia induced by PPI therapy is associated with (i) improved glucose homoeostasis, (ii) islet cell hyperplasia and (iii) increased new beta-cell formation.

\section{Patients and methods}

\section{Study design}

Pancreatic tissue specimens from 93 patients who had undergone pancreatic surgery because of chronic pancreatitis or benign pancreatic adenomas were included in this study. The patients were identified on a retrospective basis from the Department of Surgery, St. Josef-Hospital, Ruhr-University Bochum, Germany. The study protocol was approved by the Ethics Committee of the Ruhr-University Bochum (registration number 15-5344).

\section{Patients}

Pancreatic tissue specimens from 93 patients (51 males and 42 females) who had undergone pancreatic resections for the treatment of chronic pancreatitis or pancreas adenomas, in the Department of Surgery, St. JosefHospital, Ruhr-University Bochum, between the years 2004 and 2009 were included. In all cases, the clinical diagnosis of chronic pancreatitis $(n=74)$ or pancreatic adenoma $(n=19)$ was confirmed by histological analysis carried out by an independent pathologist. Patients without sufficient amounts of pancreatic tissue to allow for morphometric analyses were excluded from this study.

All clinical data and laboratory parameters were collected by a retrospective review of the patient records from the Department of Surgery, St. Josef-Hospital, RuhrUniversity Bochum. Only measurements taken before the surgery were used for the analyses.

The diagnosis of diabetes or IGT/IFG was based on an OGTT performed before surgery in 56 cases. In the other cases, fasting glucose measurements, $\mathrm{HbA}_{1 \mathrm{c}}$ levels or the patient history was used to validate the diagnosis of diabetes.

The cases were subdivided into a group with prior PPI therapy (PPI group) and a group without prior PPI 
therapy (no PPI group). The patients in the PPI group had already been treated with PPI by their referring physicians and were continued on PPI treatment until surgery. The exact duration of PPI therapy was not available from all patients.

The PPI group comprises 60 cases (34 males and 26 females). The mean age was $53.7 \pm 12.9$ years, and the BMI was $23.0 \pm 3.7 \mathrm{~kg} / \mathrm{m}^{2}$. The respective PPI dose before surgery was $20 \mathrm{mg} /$ day in 13 cases, $40 \mathrm{mg}$ /day in 31 cases, $80 \mathrm{mg} /$ day in 14 cases, $120 \mathrm{mg} /$ day in one case and $160 \mathrm{mg}$ /day in one case. Omeprazole was used in two cases, esomeprazole in 12 cases and pantoprazole in 46 cases. The presence of diabetes was previously known in 13 patients $(21.7 \%)$, amongst whom four patients $(6.7 \%)$ were treated with oral anti-diabetic drugs (glimepiride, repaglinide, exenatide and metformin respectively) and six patients $(10.0 \%)$ were treated with insulin. A pancreatic head resection was performed in 46 cases, whereas the pancreatic tail was removed in 11 cases. In three cases, other surgical procedures were performed (one pancreaticojejunostomy and two total pancreas resections).
The 'no PPI' group comprises 33 patients (17 males and 16 females). The mean age was $52.5 \pm 13.0$ years, and the BMI was $23.5 \pm 4.1 \mathrm{~kg} / \mathrm{m}^{2}$. Diabetes was previously detected in eight patients (24.2\%), one patient (3.0\%) was on oral glucose-lowering therapy (metformin) and seven patients $(21.2 \%)$ were treated with insulin. A pancreatic head resection was performed in 24 cases, 6 patients were treated with a pancreatic tail resection, and in 3 cases, other surgical procedures were performed (one pancreas segment resection and two total pancreas resections). Detailed patient characteristics are presented in Table 1.

\section{Pancreatic tissue processing}

Pancreatic tissue samples were fixed in $4 \%$ formalin overnight at $4{ }^{\circ} \mathrm{C}$ and embedded in paraffin. Sequential $5-\mu \mathrm{m}$ sections were cut from these paraffin blocks. For subsequent analysis, pancreatic tissue sections were double stained for Ki-67 and insulin, as described previously (4). All primary and secondary antibodies were diluted in Dako Antibody Diluent with Background Reducing Components (Dako; \#S3022).

Table 1 Characteristics of patients with or without previous proton pump inhibitor (PPI) therapy. Data are presented as mean \pm S.D. The numbers in brackets indicate the number of patients in whom the respective information was available. $P$-value was obtained by Student's $t$-test and Fisher's exact test.

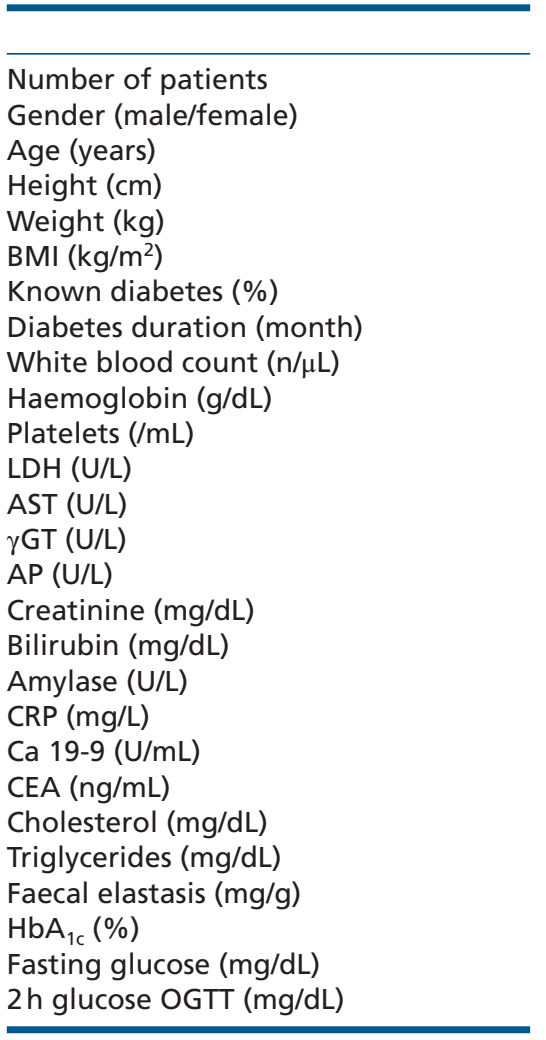

\begin{tabular}{c}
\hline PPI therapy \\
60 \\
$34 / 26(60)$ \\
$53.7 \pm 12.90(60)$ \\
$172.6 \pm 8.50(60)$ \\
$68.5 \pm 11.4(60)$ \\
$23.0 \pm 3.7(60)$ \\
$21.7(60)$ \\
$26.50 \pm 40.70(10)$ \\
$6596 \pm 269.7(60)$ \\
$13.38 \pm 0.19(60)$ \\
$269415 \pm 13942(60)$ \\
$188.4 \pm 4.75(60)$ \\
$30.90 \pm 3.14(60)$ \\
$112.0 \pm 32.25(60)$ \\
$115.8 \pm 18.98(60)$ \\
$0.94 \pm 0.03(60)$ \\
$0.60 \pm 0.05(59)$ \\
$62.98 \pm 30.34(60)$ \\
$9.20 \pm 1.37(60)$ \\
$23.46 \pm 5.09(58)$ \\
$2.51 \pm 0.25(58)$ \\
$188.1 \pm 9.07(25)$ \\
$163.1 \pm 14.74(22)$ \\
$267.7 \pm 31.26(39)$ \\
$6.14 \pm 0.13(53)$ \\
$109.4 \pm 27.3(58)$ \\
$160.6 \pm 77.9(35)$ \\
\end{tabular}

\begin{tabular}{c}
\hline No PPI therapy \\
\hline 33 \\
$17 / 16(33)$ \\
$52.5 \pm 13.00(33)$ \\
$173.1 \pm 9.0(33)$ \\
$70.2 \pm 13.1(33)$ \\
$23.5 \pm 4.1(33)$ \\
$24.2(33)$ \\
$77.17 \pm 62.71(6)$ \\
$7499 \pm 458.9(33)$ \\
$13.22 \pm 0.29(33)$ \\
$281033 \pm 17991(33)$ \\
$187.1 \pm 8.27(33)$ \\
$34.67 \pm 5.27(33)$ \\
$147.8 \pm 59.37(33)$ \\
$129.5 \pm 28.57(33)$ \\
$0.90 \pm 0.03(33)$ \\
$0.73 \pm 0.20(33)$ \\
$61.27 \pm 12.58(33)$ \\
$14.73 \pm 5.70(33)$ \\
$22.42 \pm 6.13(31)$ \\
$2.59 \pm 0.39(30)$ \\
$197.3 \pm 11.46(16)$ \\
$151.5 \pm 24.74(15)$ \\
$365.9 \pm 52.56(19)$ \\
$6.38 \pm 1.07(28)$ \\
$115.2 \pm 27.3(33)$ \\
$192.0 \pm 108.0(21)$ \\
\end{tabular}

\begin{tabular}{c}
\hline P value \\
\hline- \\
0.67 \\
0.67 \\
0.58 \\
0.82 \\
0.58 \\
0.80 \\
0.07 \\
0.07 \\
0.63 \\
0.62 \\
0.88 \\
0.51 \\
0.56 \\
0.68 \\
0.40 \\
0.44 \\
0.97 \\
0.23 \\
0.90 \\
0.85 \\
0.53 \\
0.67 \\
0.10 \\
0.30 \\
0.34 \\
0.21 \\
\end{tabular}


In brief, immunohistochemistry was performed as follows: After heating sections at $37^{\circ} \mathrm{C}$ overnight, sections were deparaffinized using xylene twice for $10 \mathrm{~min}$, followed by $\mathrm{EtOH}(100,96,80$ and 70\%) for $5 \mathrm{~min}$ (each step) and distilled water for another 5 min. 70\% EtOH contained 3\% hydrogen peroxide to block endogenous peroxidase activity. The sections were permeabilized by heating them in a steamer in DakoCytomation Target Retrieval Solution pH 9.0 (Dako; \#S2367) for $20 \mathrm{~min}$. After a $60 \mathrm{~min}$ episode of cooling and rinsing in distilled water, sections were blocked for unspecific protein binding with TBS containing 3\% BSA and $0.2 \%$ Triton X-100 for 30 min. Afterwards, the sections were blocked for endogenous biotin by the use of the DakoCytomation Biotin Blocking System (Dako; \#X0590). Then, the sections were incubated with the primary antibody monoclonal mouse anti-human Ki-67 (diluted 1:100; Dako; \#M7240) overnight at $4^{\circ} \mathrm{C}$. Subsequently, after a brief rinse in TBS (Dako; \#S3006), Ki-67 was detected with the use of the Dako REAL EnVision Detection System Peroxidase/DAB (Dako; \#K5007). For staining with insulin, tissue sections were incubated with the primary guinea pig antibody against insulin (diluted 1:400; Dako; \#A0564) for $30 \mathrm{~min}$ at $37^{\circ} \mathrm{C}$. The slides were then washed in TBS, and insulin was detected using Dako REAL Detection System Alkaline Phosphatase/RED (Dako; \#K5005). Afterwards, sections were counterstained with haematoxylin for $20 \mathrm{~s}$ and then incubated in tap water for $5 \mathrm{~min}$.

The sections were subjected through ascending alcohol concentrations (70, 80, 96 and 100\%) and xylene (each step for $5 \mathrm{~min}$ ). Finally, samples were coverslipped under Entellan (Merck; \#1079610). The slides were stored at room temperature in the darkness to minimize
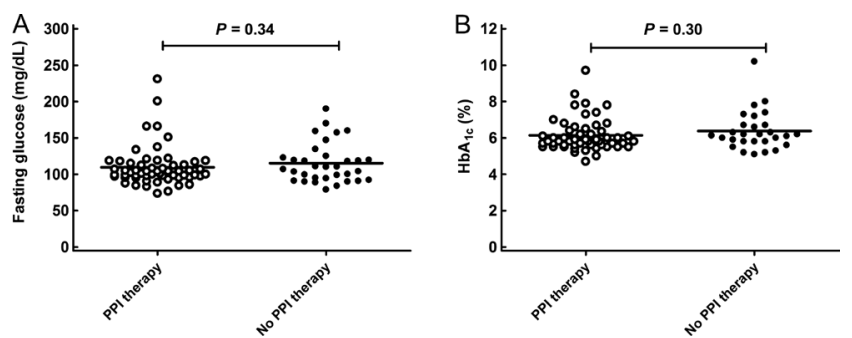

\section{Figure 1}

Fasting blood glucose $(\mathrm{A})$ and $\mathrm{HbA}_{1 \mathrm{c}}(\mathrm{B})$ values of 60 patients with and 33 patients without previous proton pump inhibitor treatment. Data are shown as individual numbers with mean values (vertical lines). $P$ values were calculated using Student's $t$-test.

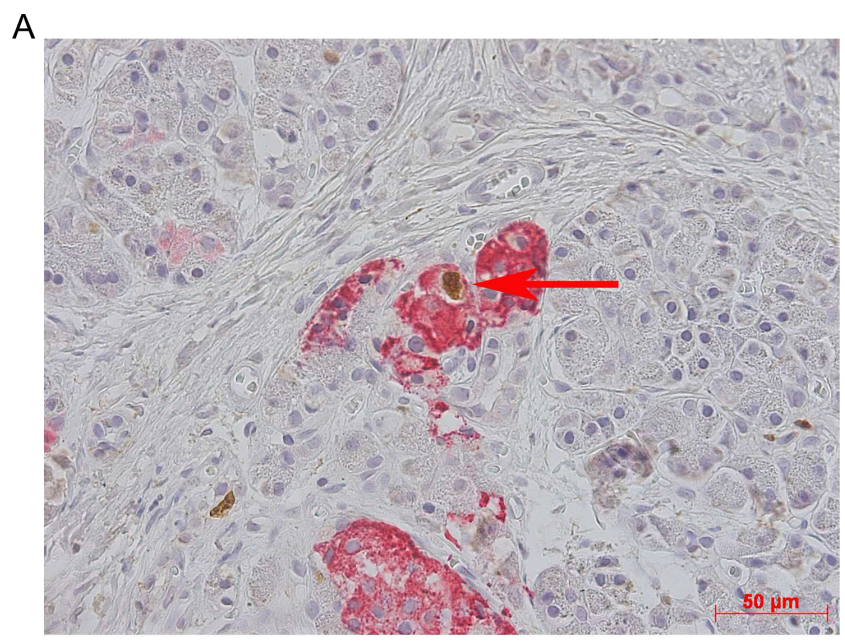

B

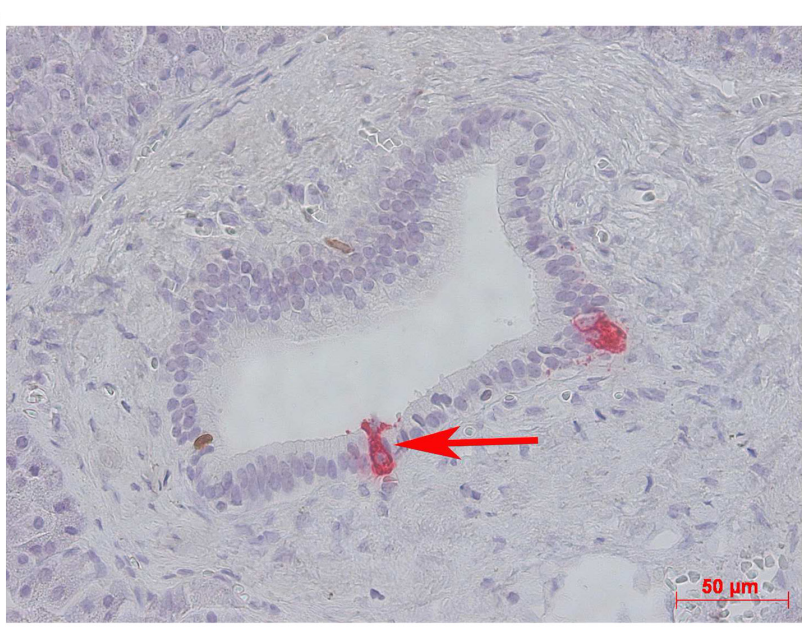

C

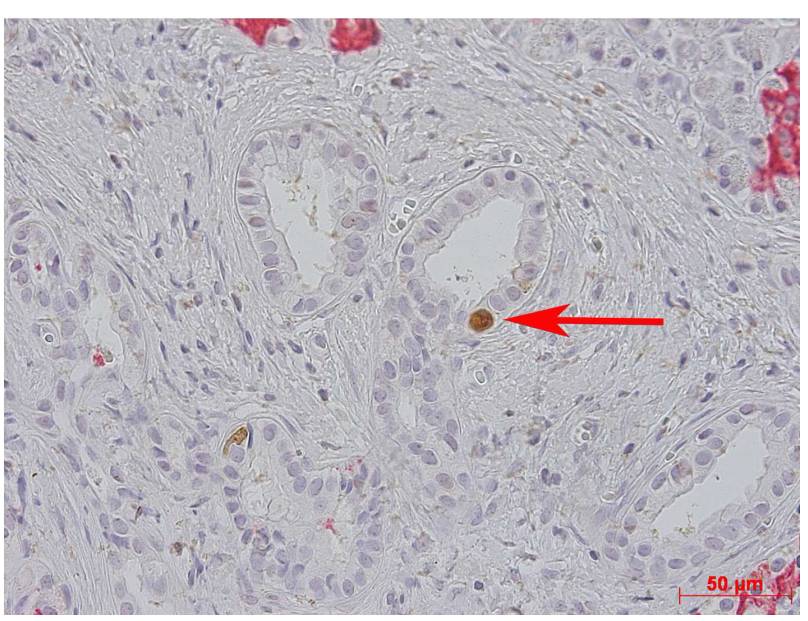

Figure 2

Representative pancreatic tissue sections stained for insulin (red) and Ki67 (brown) and imaged at 20x objective magnification. Examples of beta-cell replication (A), insulinpositive duct cells (B) and duct-cell replication (C) are displayed. 
fading. No staining could be observed when the primary antibodies were omitted.

\section{Morphometric analysis}

For the determination of the fractional $\beta$-cell area, the entire pancreatic sections stained for insulin and Ki67 were imaged using a Zeiss Axioplan microscope equipped with a motorized stage at 50x magnification (5x objective). A tile image of the tissue section was generated using the 'MosaiX' tool of the software AxioVision, version 4.5 (Zeiss). The fractional area of the pancreas that stained positive for insulin was digitally evaluated using a colour-based threshold in Zeiss AxioVision software, as described previously (4).

To determine the beta-cell proliferation, the entire tissue section that stained for insulin and Ki67 was examined for Ki67-positive beta cells, and the respective tissue area that stained for insulin was digitally measured. Thus, beta-cell replication was expressed as the number of proliferating beta cells per beta-cell area $\left(\mathrm{mm}^{2}\right)$.

For the quantification of proliferation in exocrine ducts, 10 random locations per section that stained for insulin and Ki67 were imaged at 200x magnification (20x objective) using a Zeiss Axioplan microscope.
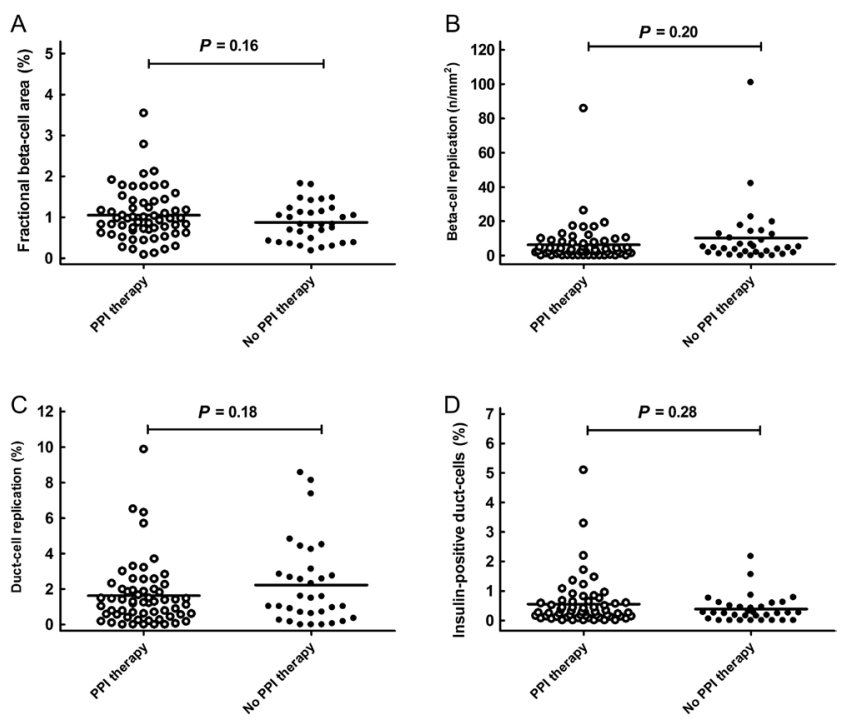

\section{Figure 3}

Fractional beta-cell area (A), beta-cell replication (B), duct-cell replication (C) and insulin-positive duct cells (D) of 60 patients with and 33 patients without previous proton pump inhibitor treatment. Data are shown as individual numbers with mean values (vertical lines). $P$ values were calculated using Student's $t$-test.
Pancreatic ducts were identified by their typical shape and appearance. A detailed description on the identification of exocrine ducts has been provided previously (4). The total number of duct cells and Ki67-positive duct cells was quantified in each field. To evaluate the relationship between $\beta$-cells and exocrine ducts as a possible surrogate marker for islet neogenesis, the number of duct cells expressing insulin was quantified and expressed as a percentage of the total number of duct cells.

For the determination of the beta-cell diameter, sections stained for insulin and Ki67 were imaged at $400 \times$ magnification (40× objective) using a Zeiss Axioplan microscope. Five islets per individual selected at random were photographed. For the determination of the mean cell diameter, the distances between two adjacent beta-cell nuclei (from center to center) of twenty beta-cells were measured in each of the five islets. The mean beta-cell diameter was calculated as the average of the measured cell diameters, as described previously (15).

All quantitative and qualitative morphological analyses were performed in a blinded fashion.

\section{Statistical analysis}

Patient characteristics are described as mean \pm s.D.; results are presented as mean \pm S.E.M. Statistical comparisons were performed using unpaired ANOVA, followed by Duncan's post hoc tests or Student's $t$-test. Numeric parameters were compared using Fisher's exact test or chisquare test. Linear regression analyses were performed using GraphPad Prism 6. A $P$ value $<0.05$ was taken as an indicator for significant differences.

\section{Results}

The groups were matched for gender, age, BMI and presence of diabetes (Table 1). There were also no significant differences with regard to haematological parameters, kidney function, pancreas enzymes, liver enzymes and lipids (Table 1).

To address whether PPI therapy had an impact on glucose homeostasis, fasting glucose and $\mathrm{HbA}_{1 \mathrm{c}}$ levels were compared. Fasting glucose was $109.4 \pm 3.6 \mathrm{mg} / \mathrm{dL}$ in the PPI group and $115.2 \pm 4.8 \mathrm{mg} / \mathrm{dL}$ in the no PPI group $(P=0.34) . \mathrm{HbA}_{1 \mathrm{c}}$ levels were $6.14 \pm 0.13 \%$ in the PPI group and $6.38 \pm 0.20 \%$ in the control group $(P=0.30)$ (Fig. 1$)$.

Pancreatic morphology was unremarkable in the tumour-free tissue sections of the patients presenting with adenomas. In contrast, pancreatic tissue sections of 
patients with chronic pancreatitis exhibited characteristic changes and often presented with periductal fibrosis, strains of collagen fibres, pronounced pseudolobular arrangement and significant loss of acinar tissue. However, there were no obvious specific alterations in pancreatic morphology in patients with previous PPI treatment (Fig. 2).

Fractional beta-cell area of the pancreas was subjected to large heterogeneity, ranging from 0.08 to $3.54 \%$ (44fold difference; Fig. 3). As expected, beta-cell area was higher in patients without diabetes than that in patients with IGT or IFG and patients with diabetes $(1.33 \pm 0.12 \%$, $1.05 \pm 0.09 \%$ and $0.66 \pm 0.07 \%$ respectively; $P<0.0001$ ). Fractional beta-cell area was not different between the specimens collected from the pancreatic head and the pancreatic tail $(0.98 \pm 0.07 \%$ vs $1.07 \pm 0.18 \%$ respectively; $P=0.56)$. There was no difference in fractional beta-cell area between patients with and without previous PPI treatment $(1.05 \pm 0.08 \%$ vs $0.87 \pm 0.08 \%$ respectively; $P=0.16$; Fig. 3). In addition, when the groups of patients without diabetes, with IGT or IFG and with diabetes were analysed separately, no differences in beta-cell area were found between patients with and without previous PPI therapy (Fig. 4).
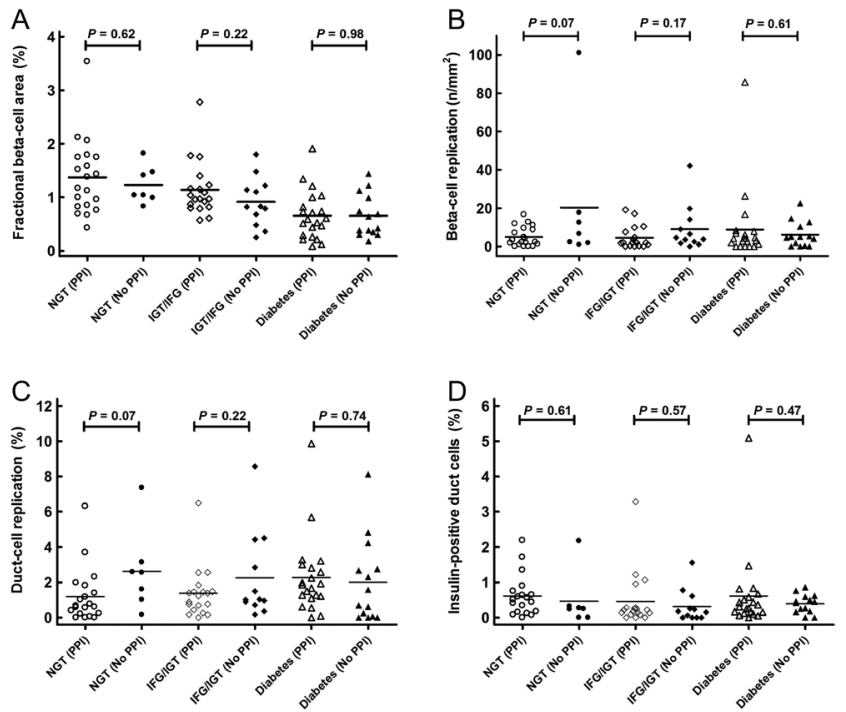

Figure 4

Fractional beta-cell area (A), beta-cell replication (B), duct-cell replication (C) and insulin-positive duct cells (D) of 93 patients without diabetes, with pre-diabetes (impaired fasting glucose (IFG)/impaired glucose tolerance (IGT)) or with diabetes with or without previous proton pump inhibitor treatment. Data are shown as individual numbers with mean values (vertical lines). $P$ values were calculated using Student's $t$-test.
Fractional beta-cell area, beta-cell replication, ductcell replication and the number of insulin-positive duct cells were not different among the various doses of PPI treatment (Fig. 5).

Beta-cell size was similar between patients with and without previous PPI treatment $(9.83 \pm 0.19 \mu \mathrm{m}$ vs $9.73 \pm 0.15 \mu \mathrm{m}$ respectively; $P=0.63$; Fig. 6). There was no difference among the groups of patients without diabetes, with IGT/IFG and with diabetes $(9.60 \pm 0.22 \mu \mathrm{m}$, $9.86 \pm 0.13 \mu \mathrm{m}$ and $9.89 \pm 0.15 \mu \mathrm{m}$ respectively; $P=0.12$ ). In addition, when these groups were analysed separately, no differences in beta-cell size were found between patients with and without previous PPI therapy (Fig. 6).

Beta-cell replication was found infrequently in the tissue sections from patients treated with PPI and controls. There were no significant differences in beta-cell replication among the groups $\left(6.25 \pm 1.53\right.$ cells $/ \mathrm{mm}^{2}$ vs $10.28 \pm 3.21$ cells $/ \mathrm{mm}^{2}$ for the PPI and the no PPI group respectively; $P=0.20$; Fig. 3). This result was consistent, when the groups of patients without diabetes, with prediabetes and with diabetes were analysed separately (Fig. 4). The frequency of beta-cell replication was not different among the groups of patients without diabetes, with IGT/IFG and with diabetes $\left(9.02 \pm 3.68\right.$ cells $/ \mathrm{mm}^{2}$, $6.33 \pm 1.58$ cells $/ \mathrm{mm}^{2}$ and $7.84 \pm 2.53$ cells $/ \mathrm{mm}^{2}$ respectively; $P=0.78$; Fig. 4 ).
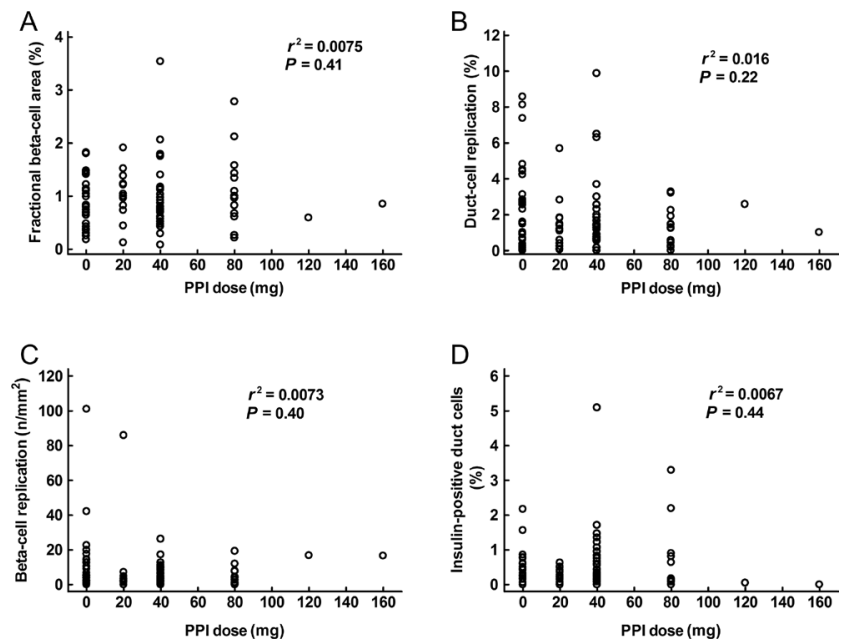

\section{Figure 5}

Fractional beta-cell area (A), duct-cell replication (B), beta-cell replication (C) and insulin-positive duct cells (D) in relation to dose of the PPI treatment in 60 patients with and 33 patients without previous proton pump inhibitor treatment. Data are shown as individual numbers. $r^{2}$ and $P$ values were calculated by linear regression analysis. 

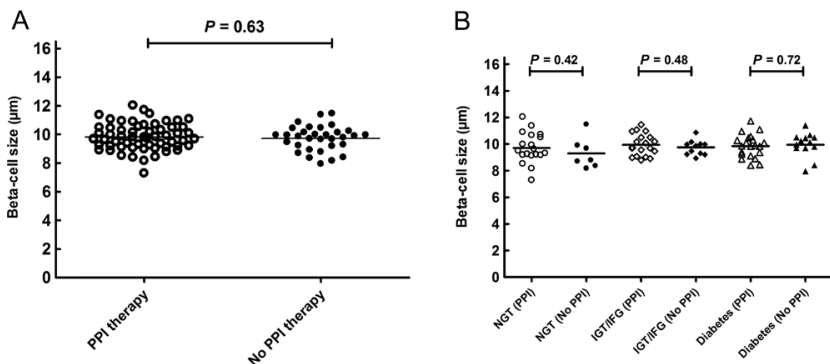

\section{Figure 6}

(A) Beta-cell size in 60 patients with and 33 patients without PPI therapy. (B) Beta-cell size in patients with and without PPI therapy grouped according to the presence of normal glucose tolerance (NGT), impaired glucose tolerance (IGT) or impaired fasting glucose (IFG) or diabetes. Data are shown as individual numbers with mean values (vertical lines). $P$ values were calculated using Student's $t$-test.

Expression of Ki67 was readily observed in acinar cells and in exocrine pancreatic ducts. The percentage of replicating duct cells was $1.64 \pm 0.24 \%$ in the PPI group and $2.23 \pm 0.41 \%$ in the no PPI group $(P=0.18$; Fig. 3). Duct-cell replication was not different among patients without diabetes, with IGT or IFG and with diabetes $(1.56 \pm 0.35 \%, 1.71 \pm 0.35 \%$ and $2.17 \pm 0.38 \%$ respectively; $P=0.46$ ). Expression of Ki67 in duct cells was also not different between patients treated with and without PPIs, when the groups of patients without diabetes, with IGT or IFG and with diabetes were analysed separately (Fig. 4).

A significant correlation between the percentage of duct cells expressing $\mathrm{Ki} 67$ and the respective frequency of beta-cell replication was observed $\left(r^{2}=0.091 ; P=0.0033\right.$; details not shown).

The percentage of duct cells expressing insulin was not different between patients with and without previous PPI treatment $(0.55 \pm 0.11 \%$ vs $0.38 \pm 0.08 \%$ respectively; $P=0.28$; Fig. 3). This result was consistent, when the groups of patients without diabetes, with pre-diabetes and with diabetes were analysed separately (Fig. 4). There was also no difference in the frequency of insulinpositive duct cells among patients without diabetes, with IGT/IFG or with diabetes $(0.55 \pm 0.12 \%, 0.41 \pm 0.12 \%$ and $0.52 \pm 0.14 \%$ respectively; $P=0.72$ ).

\section{Discussion}

This study was designed to examine whether patients treated with PPIs exhibit differences in glucose control, pancreatic beta-cell area or new beta-cell formation compared with patients without prior PPI therapy. Based on the quantitative morphologic evaluation of pancreatic specimens from 93 patients, we did not find any differences between patients with and without prior PPI therapy. There were also no differences in glucose control between the groups.

A role for gastrin in the regulation of beta-cell regeneration has first been proposed based on the observation of islet hyperplasia in patients with gastrinomas (31). These results were later extended by the observation of increased islet cell replication adjacent to intrapancreatic gastrinomas (10). Furthermore, the high expression rates of gastrin/cholezystokinin receptors in the neonatal pancreas have supported a role of the peptide in beta-cell proliferation $(32,33)$.

Exogenous gastrin therapy has also promoted beta-cell expansion in various experimental models, such as NOD mice (26). Interestingly, gastrin treatment was only found effective in combination with other proliferative stimuli, such as GLP-1, DPP-4 inhibitors, epidermal growth factor, previous duct ligation or partial pancreatectomy (25, $27,28,29,34)$. The proposed molecular mechanism of gastrin's action on beta-cell regeneration includes an induction of differentiation of ductal cells into endocrine cells, as suggested by an increased expression of endocrine markers, such as neurogenin 3 or nkx6.1 (35, 36). Furthermore, a recovery of insulin expression, as well as increased beta-cell replication, has been described in alloxan-induced diabetic mice (37).

It has also been suggested that gastrin may exert a functional role in stimulating insulin secretion. Thus, a number of studies have reported a glucose-dependent increase in insulin secretion after exogenous gastrin administration $(38,39,40)$. However, this finding was not confirmed by other studies $(41,42)$ and appears to be relevant only at highly supraphysiological plasma concentrations (43).

Because endogenous gastrin levels can also be raised by blocking gastric acid secretion, PPI treatment has recently been examined in combination with a DPP-4 inhibitor in immunodeficient mice after human pancreatic duct-cell transplantation (34). These studies reported improvements in glucose control as well as marked increases in insulin expression in the pancreatic grafts.

In humans, evidence for an effect of PPIs on glucose control under in vivo conditions is still sparse, although PPIs are amongst the most often used drugs worldwide. Two retrospective analyses of patients with type 2 diabetes showed significantly lower $\mathrm{HbA}_{1 \mathrm{c}}$ levels in patients treated with PPIs $(44,45)$. These results were confirmed by a 
randomized controlled trial showing significantly lower $\mathrm{HbA}_{1 \mathrm{c}}$ levels in 16 patients with type 2 diabetes treated with pantoprazole than those in 15 patients receiving placebo over 12 weeks (46). In contrast, no differences in $\mathrm{HbA}_{1 \mathrm{c}}$ levels or insulin secretion were found in another recent study that examined the effects of 12-week treatment with esomeprazole in 41 patients with type 2 diabetes, despite a 9-fold increase in endogenous gastrin levels (47).

The present data showing no differences in either glucose control or fractional beta-cell area and size between patients treated with and without PPIs are in line with the latter study. The discrepancies between the various studies conducted in rodent or human models may be explained by different factors: First, it is obvious that gastrin or PPI treatment was only effective in combination with other stimuli, such as GLP-1, DPP-4 inhibitors, epidermal growth factor, previous duct ligation or partial pancreatectomy in the majority of rodent studies $(25,27,28,29,34)$. In line with this, we have previously noticed that islet hyperplasia and increased beta-cell proliferation were only apparent in the direct proximity of intrapancreatic gastrinomas, where putatively the local concentrations of other tumourderived growth factors were also largely increased (10). Thus, raising gastrin levels alone may not be sufficient to exert a significant effect on beta-cell mass or function. Second, most rodent studies have examined animals of rather young age, which typically exhibit a high capacity for new beta-cell formation on various stimuli $(28,29)$. However, several studies have now demonstrated that the potential for beta-cell regeneration declines sharply with ageing $(19,20)$, which might contribute to the lack of effect of PPI treatment in this study. Along these lines, beta-cell regeneration has been observed after partial pancreatectomy, streptozotocin treatment or GLP-1 receptor agonist treatment in young rodents, but not in adult animals or humans $(20,48)$. Third, the number of patients included in the randomized prospective trials with PPIs was relatively small and might not be sufficient to fully exclude small effects in a larger trial setting. Finally, other clinical conditions or dietary habits leading to chronic PPI therapy might have influenced the results of the retrospective studies. Overall, the presently available data do not yet allow for final conclusions regarding the effects of gastrin on glucose homoeostasis or beta-cell regeneration in humans, although large effects seem rather unlikely.

A number of limitations must be considered with respect to this study. Because of the retrospective study design, the clinical information on the patients was not always complete. Furthermore, all patients included in this study had undergone pancreatic surgery for the treatment of either chronic pancreatitis or pancreatic adenomas. It cannot be fully excluded that the pancreatic alterations induced by these comorbidities had an independent effect on beta-cell mass, beta-cell size or turnover, although the confounding effect of such factors should have been balanced amongst the groups.

The frequency of beta-cell replication measured in this study appears to be higher than that reported in previous studies (10). These differences might be due to different conditions of tissue collection, fixation or duration of storage. In this study, freshly fixed tissue samples collected at surgery were obtained without differences in the tissue processing procedures between the groups. It is also possible that the underlying disease conditions (especially chronic pancreatitis) had an independent effect on the frequency of beta-cell proliferation. Furthermore, the mean values for betacell replication in this study were rather high because of some few outlier patients (Fig. 5C). This phenomenon of single cases with unusually high frequencies has been recognized previously in the literature in brain-dead organ donors (9).

One might also argue that induction of beta-cell regeneration by gastrin would only occur in patients with diabetes. Therefore, we have performed a separate analysis in the group of patients with diabetes, which did not reveal any evidence of improved glucose control or islet hyperplasia after PPI treatment either. Finally, circulating gastrin levels were not available in these patients. However, hypergastrinaemia has been well documented during PPI therapy in numerous previous studies (47, 49). A specific strength of the present analysis is the high number of human tissue specimens, which is far in excess of many prior studies on the human pancreas $(10,50)$.

Although increased beta-cell mass after gastrin or PPI therapy has been noticed in numerous previous rodent studies, the exact mechanisms of new beta-cell formation are still debated. Rooman et al. noticed an increase in the number of single, extra-insular beta cells and small betacell clusters after gastrin treatment following pancreatic duct ligation in rats, suggesting increased beta-cell neogenesis $(25,27)$. In line with this, Suarez-Pinzon et al. have suggested an induction of islet neogenesis by gastrin treatment in a number of experimental models (26, $28,34)$. Notably, increased insulin expression was also demonstrated in human pancreatic duct cells after EGF and gastrin treatment (34). In contrast, increased beta-cell 
replication was reported in human pancreatic tissue adjacent to intrapancreatic gastrinomas (10). In this study, we have applied measures of both beta-cell replication (Ki67 staining) and surrogate markers of islet neogenesis (insulin expression in ducts) to take into account both pathways. However, there was no difference in either of these parameters, in line with the lack of beta-cell hyperplasia in the PPI-treated patients.

This study also confirms the previous observation of a reduction in pancreatic beta-cell area in patients with diabetes $(1,51)$, thereby underlining the importance of beta-cell mass for the maintenance of normoglycaemia. Furthermore, in the present group of patients, there was no difference in beta-cell replication, duct-cell replication or the percentage of insulin-positive duct cells between patients with and without diabetes.

In conclusion, in this study PPI treatment was not associated with changes in glucose control, islet morphology or new beta-cell formation. These results suggest that in adult humans, chronic PPI treatment does not enhance beta-cell mass to a relevant extent.

\section{Declaration of interest}

The authors declare that there is no conflict of interest that could be perceived as prejudicing the impartiality of the research reported.

\section{Funding}

These studies were supported by the Deutsche Forschungsgemeinschaft (DFG ME-2096/5-2).

\section{Acknowledgements}

The technical assistance of Birgit Baller and Mechthild Schweinsberg is gratefully acknowledged. The authors are indebted to Dr Sandra Überberg for her help with the histological analyses. These studies were supported by the Deutsche Forschungsgemeinschaft (DFG ME-2096/5-2).

\section{References}

1 Butler AE, Janson J, Bonner-Weir S, Ritzel R, Rizza RA \& Butler PC. Beta-cell deficit and increased beta-cell apoptosis in humans with type 2 diabetes. Diabetes 200352 102-110. (doi:10.2337/diabetes.52.1.102)

2 Meier JJ, Bhushan A, Butler AE, Rizza RA \& Butler PC. Sustained beta cell apoptosis in patients with long-standing type 1 diabetes: indirect evidence for islet regeneration? Diabetologia 200548 2221-2228. (doi:10.1007/s00125-005-1949-2)

3 Kloppel G, Drenck CR, Oberholzer M \& Heitz PU. Morphometric evidence for a striking B-cell reduction at the clinical onset of type 1 diabetes. Virchows Archiv A: Pathological Anatomy and Histopathology 1984403 441-452. (doi:10.1007/BF00737292)

4 Schrader H, Menge BA, Schneider S, Belyaev O, Tannapfel A, Uhl W, Schmidt WE \& Meier JJ. Reduced pancreatic volume and beta-cell area in patients with chronic pancreatitis. Gastroenterology 2009136 513-522. (doi:10.1053/j.gastro.2008.10.083)
5 Halban PA. Cellular sources of new pancreatic beta cells and therapeutic implications for regenerative medicine. Nature Cell Biology 20046 1021-1025. (doi:10.1038/ncb1104-1021)

6 Meier JJ, Bhushan A \& Butler PC. The potential for stem cell therapy in diabetes. Pediatric Research 200659 65R-73R. (doi:10.1203/ 01.pdr.0000206857.38581.49)

7 Bonner-Weir S, Li WC, Ouziel-Yahalom L, Guo L, Weir GC \& Sharma A. Beta-cell growth and regeneration: replication is only part of the story. Diabetes 201059 2340-2348. (doi:10.2337/db10-0084)

8 Kassem SA, Ariel I, Thornton PS, Scheimberg I \& Glaser B. Beta-cell proliferation and apoptosis in the developing normal human pancreas and in hyperinsulinism of infancy. Diabetes 2000 49 1325-1333. (doi:10.2337/diabetes.49.8.1325)

9 In't Veld P, De Munck N, Van Belle K, Buelens N, Ling Z, Weets I, Haentjens P, Pipeleers-Marichal M, Gorus F \& Pipeleers D. Beta-cell replication is increased in donor organs from young patients after prolonged life support. Diabetes 201059 1702-1708. (doi:10.2337/ db09-1698)

10 Meier JJ, Butler AE, Galasso R, Rizza RA \& Butler PC. Increased islet beta cell replication adjacent to intrapancreatic gastrinomas in humans. Diabetologia 200649 2689-2696. (doi:10.1007/s00125006-0410-5)

11 Meier JJ, Butler AE, Saisho Y, Monchamp T, Galasso R, Bhushan A, Rizza RA \& Butler PC. Beta-cell replication is the primary mechanism subserving the postnatal expansion of beta-cell mass in humans. Diabetes 200857 1584-1594. (doi:10.2337/db07-1369)

12 Butler PC, Meier JJ, Butler AE \& Bhushan A. The replication of beta cells in normal physiology, in disease and for therapy. Nature Clinical Practice Endocrinology \& Metabolism 20073 758-768. (doi:10.1038/ ncpendmet0647)

13 Kohler CU, Olewinski M, Tannapfel A, Schmidt WE, Fritsch H \& Meier JJ. Cell cycle control of beta-cell replication in the prenatal and postnatal human pancreas. American Journal of Physiology Endocrinology and Metabolism 2011300 E221-E230. (doi:10.1152/ ajpendo.00496.2010)

14 Meier JJ, Lin JC, Butler AE, Galasso R, Martinez DS \& Butler PC. Direct evidence of attempted beta cell regeneration in an 89-year-old patient with recent-onset type 1 diabetes. Diabetologia 200649 1838-1844. (doi:10.1007/s00125-006-0308-2)

15 Butler AE, Cao-Minh L, Galasso R, Rizza RA, Corradin A, Cobelli C $\&$ Butler PC. Adaptive changes in pancreatic beta cell fractional area and beta cell turnover in human pregnancy. Diabetologia 201053 2167-2176. (doi:10.1007/s00125-010-1809-6)

16 Buteau J, Foisy S, Rhodes CJ, Carpenter L, Biden TJ \& Prentki M. Protein kinase $C_{\text {zeta }}$ activation mediates glucagon-like peptide-1induced pancreatic beta-cell proliferation. Diabetes 200150 2237-2243. (doi:10.2337/diabetes.50.10.2237)

17 Sturis J, Gotfredsen CF, Rømer J, Rolin B, Ribel U, Brand CL, Wilken M, Wassermann K, Deacon CF, Carr RD et al. GLP-1 derivative liraglutide in rats with beta-cell deficiencies: influence of metabolic state on beta-cell mass dynamics. British Journal of Pharmacology 2003 140 123-132. (doi:10.1038/sj.bjp.0705397)

18 Stoffers DA, Kieffer TJ, Hussain MA, Drucker DJ, Bonner-Weir S, Habener JF \& Egan JM. Insulinotropic glucagon-like peptide 1 agonists stimulate expression of homeodomain protein IDX-1 and increase islet size in mouse pancreas. Diabetes 200049 741-748. (doi:10.2337/diabetes.49.5.741)

19 Tschen SI, Dhawan S, Gurlo T \& Bhushan A. Age-dependent decline in beta-cell proliferation restricts the capacity of beta-cell regeneration in mice. Diabetes 200958 1312-1320. (doi:10.2337/db08-1651)

20 Rankin MM \& Kushner JA. Adaptive beta-cell proliferation is severely restricted with advanced age. Diabetes 200958 1365-1372. (doi:10.2337/db08-1198)

21 Tokui Y, Kozawa J, Yamagata K, Zhang J, Ohmoto H, Tochino Y, Okita K, Iwahashi H, Namba M, Shimomura I et al. Neogenesis and proliferation of beta-cells induced by human betacellulin gene 
transduction via retrograde pancreatic duct injection of an adenovirus vector. Biochemical and Biophysical Research Communications 2006350 987-993. (doi:10.1016/j.bbrc.2006.09.154)

22 Nielsen JH, Galsgaard ED, Moldrup A, Friedrichsen BN, Billestrup N, Hansen JA, Lee YC \& Carlsson C. Regulation of beta-cell mass by hormones and growth factors. Diabetes 200150 (Supplement 1) S25-29. (doi:10.2337/diabetes.50.2007.S25)

23 Kim H, Toyofuku Y, Lynn FC, Chak E, Uchida T, Mizukami H, Fujitani Y, Kawamori R, Miyatsuka T, Kosaka Y et al. Serotonin regulates pancreatic beta cell mass during pregnancy. Nature Medicine 201016 804-808. (doi:10.1038/nm.2173)

24 Lingohr MK, Dickson LM, McCuaig JF, Hugl SR, Twardzik DR \& Rhodes CJ. Activation of IRS-2-mediated signal transduction by IGF-1, but not TGF-alpha or EGF, augments pancreatic beta-cell proliferation. Diabetes 200251 966-976. (doi:10.2337/diabetes.51.4.966)

25 Rooman I, Lardon J \& Bouwens L. Gastrin stimulates beta-cell neogenesis and increases islet mass from transdifferentiated but not from normal exocrine pancreas tissue. Diabetes 200251 686-690. (doi:10.2337/diabetes.51.3.686)

26 Suarez-Pinzon WL, Yan Y, Power R, Brand SJ \& Rabinovitch A. Combination therapy with epidermal growth factor and gastrin increases beta-cell mass and reverses hyperglycemia in diabetic NOD mice. Diabetes 200554 2596-2601. (doi:10.2337/diabetes.54.9.2596)

27 Rooman I \& Bouwens L. Combined gastrin and epidermal growth factor treatment induces islet regeneration and restores normoglycaemia in C57B16/J mice treated with alloxan. Diabetologia 200447 259-265. (doi:10.1007/s00125-003-1287-1)

28 Suarez-Pinzon WL, Power RF, Yan Y, Wasserfall C, Atkinson M \& Rabinovitch A. Combination therapy with glucagon-like peptide-1 and gastrin restores normoglycemia in diabetic NOD mice. Diabetes 200857 3281-3288. (doi:10.2337/db08-0688)

29 Tellez N, Joanny G, Escoriza J, Vilaseca M \& Montanya E. Gastrin treatment stimulates beta-cell regeneration and improves glucose tolerance in 95\% pancreatectomized rats. Endocrinology 2011152 2580-2588. (doi:10.1210/en.2011-0066)

30 Creutzfeldt $\mathrm{W} \&$ Lamberts R. Is hypergastrinaemia dangerous to man? Scandinavian Journal of Gastroenterology. Supplement 1991 180 179-191. (doi:10.3109/00365529109093198)

31 Creutzfeldt W, Arnold R, Creutzfeldt C \& Track NS. Pathomorphologic, biochemical, and diagnostic aspects of gastrinomas (Zollinger-Ellison syndrome). Human Pathology 19756 47-76. (doi:10.1016/S0046-8177(75)80109-2)

32 Brand SJ \& Fuller PJ. Differential gastrin gene expression in rat gastrointestinal tract and pancreas during neonatal development. Journal of Biological Chemistry 1988263 5341-5347.

33 Larsson LI, Rehfeld JF, Sundler F \& Hakanson R. Pancreatic gastrin in foetal and neonatal rats. Nature 1976262 609-610. (doi:10.1038/262609a0)

34 Suarez-Pinzon WL \& Rabinovitch A. Combination therapy with a dipeptidyl peptidase- 4 inhibitor and a proton pump inhibitor induces beta-cell neogenesis from adult human pancreatic duct cells implanted in immunodeficient mice. Cell Transplantation 201120 1343-1349. (doi:10.3727/096368910X557263)

35 Tellez N, Vilaseca M, Marti Y, Pla A \& Montanya E. beta-cell dedifferentiation, reduced duct cell plasticity and impaired beta-cell mass regeneration in middle-aged rats. American Journal of Physiology Endocrinology and Metabolism 2016311 E554-E563. (doi:10.1152/ ajpendo.00502.2015)

36 Tellez N \& Montanya E. Gastrin induces ductal cell dedifferentiation and beta-cell neogenesis after $90 \%$ pancreatectomy. Journal of Endocrinology 2014223 67-78. (doi:10.1530/JOE-14-0222)
37 Song I, Patel O, Himpe E, Muller CJ \& Bouwens L. Beta cell mass restoration in Alloxan-diabetic mice treated with EGF and gastrin. PLOS ONE 201510 e0140148. (doi:10.1371/journal.pone.0140148)

38 Unger RH, Ketterer H, Dupre J \& Eisentraut AM. The effects of secretin, pancreozymin, and gastrin on insulin and glucagon secretion in anesthetized dogs. Journal of Clinical Investigation 1967 46 630-645. (doi:10.1172/JCI105565)

39 Dupre J, Curtis JD, Unger RH, Waddell RW \& Beck JC. Effects of secretin, pancreozymin, or gastrin on the response of the endocrine pancreas to administration of glucose or arginine in man. Journal of Clinical Investigation 196948 745-757. (doi:10.1172/JCI106032)

40 Kaneto A, Tasaka Y, Kosaka K \& Nakao K. Stimulation of insulin secretion by the C-terminal tetrapeptide amide of gastrin. Endocrinology 196984 1098-1106. (doi:10.1210/endo-84-5-1098)

41 Jarrett RJ \& Cohen NM. Intestinal hormones and plasma-insulin. Some observations on glucagon, secretin, and gastrin. Lancet 19672 861-863. (doi:10.1016/S0140-6736(67)92594-9)

42 Lazarus NR, Voyles NR, Devrim S, Tanese T \& Recant L. Extra-gastrointestinal effects of secretin, gastrin, and pancreozymin. Lancet 19682 248-250. (doi:10.1016/S0140-6736(68)92353-2)

43 Rehfeld JF \& Stadil F. The effect of gastrin on basal- and glucosestimulated insulin secretion in man. Journal of Clinical Investigation 197352 1415-1426. (doi:10.1172/JCI107315)

44 Crouch MA, Mefford IN \& Wade EU. Proton pump inhibitor therapy associated with lower glycosylated hemoglobin levels in type 2 diabetes. Journal of the American Board of Family Medicine 201225 50-54. (doi:10.3122/jabfm.2012.01.100161)

45 Mefford IN \& Wade EU. Proton pump inhibitors as a treatment method for type II diabetes. Medical Hypotheses 200973 29-32. (doi:10.1016/j.mehy.2009.02.010)

46 Singh PK, Hota D, Dutta P, Sachdeva N, Chakrabarti A, Srinivasan A, Singh I \& Bhansali A. Pantoprazole improves glycemic control in type 2 diabetes: a randomized, double-blind, placebo-controlled trial. Journal of Clinical Endocrinology and Metabolism 201297 E2105-E2108. (doi:10.1210/jc.2012-1720)

47 Hove KD, Brons C, Faerch K, Lund SS, Petersen JS, Karlsen AE, Rossing P, Rehfeld JF \& Vaag A. Effects of 12 weeks' treatment with a proton pump inhibitor on insulin secretion, glucose metabolism and markers of cardiovascular risk in patients with type 2 diabetes: a randomised double-blind prospective placebo-controlled study. Diabetologia 201356 22-30. (doi:10.1007/s00125-012-2714-y)

48 Menge BA, Tannapfel A, Belyaev O, Drescher R, Muller C, Uhl W, Schmidt WE \& Meier JJ. Partial pancreatectomy in adult humans does not provoke beta-cell regeneration. Diabetes 200857 142-149. (doi:10.2337/db07-1294)

49 Savarino V, Di Mario F \& Scarpignato C. Proton pump inhibitors in GORD An overview of their pharmacology, efficacy and safety. Pharmacological Research 200959 135-153. (doi:10.1016/j.phrs. 2008.09.016)

50 Butler AE, Campbell-Thompson M, Gurlo T, Dawson DW, Atkinson M \& Butler PC. Marked expansion of exocrine and endocrine pancreas with incretin therapy in humans with increased exocrine pancreas dysplasia and the potential for glucagon-producing neuroendocrine tumors. Diabetes 201362 2595-2604. (doi:10.2337/db12-1686)

51 Meier JJ, Breuer TG, Bonadonna RC, Tannapfel A, Uhl W, Schmidt WE, Schrader H \& Menge BA. Pancreatic diabetes manifests when beta cell area declines by approximately $65 \%$ in humans. Diabetologia 201255 1346-1354. (doi:10.1007/s00125012-2466-8)

Received 8 April 2016

Revised version received 9 August 2016

Accepted 24 August 2016 